\title{
ITLN1 Gene
}

National Cancer Institute

\section{Source}

National Cancer Institute. ITLN1 Gene. NCI Thesaurus. Code C124076.

This gene is involved in the modulation of insulin-dependent signaling. 